\title{
Evaluation of No-Take Zones in the Galapagos Marine Reserve, Zoning Plan 2000
}

\author{
Nicolas Moity* \\ Department of Marine Sciences, Charles Darwin Research Station, Charles Darwin Foundation, Galapagos Islands, Ecuador
}

Keywords: galapagos, zoning, no-take, GIS dataset, marine spatial planning, marine reserve

\section{INTRODUCTION}

The Galapagos Marine Reserve (GMR) was created in 1998, covering an area of 138,000 $\mathrm{km}^{2}$ that surrounds the islands of the Galapagos Archipelago. The GMR was created on the basis of a 40 nautical mile buffer from the smallest polygon that encompasses all islands boundaries. In 2001, the GMR was included as a Natural World Heritage Site due to its outstanding universal value. Located at the confluence of three major ocean currents, mixing warm and cold and nutrient rich waters, the GMR has an exceptional marine biodiversity, high level of endemicity, while having a primary production that supports a very high biomass of pelagic species (Wellington et al., 1984; Danulat and Edgar, 2002; Edgar et al., 2004a; Bustamante et al., 2008; Salinas de León et al., 2016; Boerder et al., 2017; Bucaram et al., 2018).

The GMR is managed as a multi-use protected area. This means that, while the general objective

OPEN ACCESS

Edited by:

Lyne Morissette,

M-Expertise Marine, Canada

Reviewed by:

Andrew M. Fischer,

University of Tasmania, Australia

Christos Karelakis,

Democritus University of Thrace,

Greece

*Correspondence:

Nicolas Moity

nicolas.moity@fcdarwin.org.ec

n.moity@gmail.com

Specialty section:

This article was submitted to

Marine Affairs and Policy,

a section of the journal

Frontiers in Marine Science

Received: 01 March 2018

Accepted: 26 June 2018

Published: 17 July 2018

Citation:

Moity N (2018) Evaluation of No-Take

Zones in the Galapagos Marine

Reserve, Zoning Plan 2000.

Front. Mar. Sci. 5:244.

doi: 10.3389/fmars.2018.00244 of the GMR is enhancing its conservation, some areas are reserved for local artisanal fishers (fishing use), some for the appreciation and enjoyment of the public (tourism use) and others are kept preserved in their natural state (conservation use). Industrial fishing is banned within the GMR, while artisanal fishing is permitted for registered fishermen of the local community. Because the GMR has outstanding natural values, there was a need to develop a spatial plan to guarantee the conservation of its natural resources as well as allowing an organized use of some of its areas, including the extractive use of seafood. The first zoning plan of the GMR was declared in 2000 following a consensus of the Participatory Management Board and later physically demarcated in 2006 (Castrejón and Charles, 2013). The aim of the zoning was to reduce conflicts between uses, protect marine biodiversity, and promote sustainable uses (Heylings et al., 2002). This zoning plan divided the GMR into three zones: Zone 1-the multiple use zone, which includes the deep waters of the GMR, i.e., $>300 \mathrm{~m}$ deep, where all uses are allowed in addition to navigation and surveillance. Zone 2-the limited use zone, which consists of coastal waters $(<300 \mathrm{~m})$ surrounding the islands, islets and rocks, and includes seamounts. Zone 3-port zones. Zone 2 had four management subzones: 2.1 Comparison and Protection (conservation subzone), 2.2 Conservation and NonExtractive Use (tourism subzone), 2.3 Conservation and Extractive (fishing subzone) and NonExtractive Use (tourism subzone), and 2.4 Areas of Special Temporal Management, located in the vicinity of ports and harbors which are conceived for experimental and recovery purposes in case of an anthropogenic or natural disaster (see Heylings et al., 2002 and Castrejón and Charles, 2013 for a thorough revision of the history of marine zoning in the Galapagos Marine Reserve).

According to the Galapagos National Park Management Plan (Dirección del Parque Nacional Galápagos and Fundación Charles Darwin, 1999), coastal water subzones constitute the area extending two nautical miles $(\mathrm{nm})$ from the coastline out to sea. However, even though the zoning plan was approved by consensus including 14 conservation zones, 62 tourism zones, 45 fishing zones, and 9 Areas of Special Temporal Management(Edgar et al., 2004b), the Galapagos National Park only delivered zoning maps differentiating Zone 2 management subzones along the coastline, 
but did not differentiate actual subzones (areas) within coastal waters, i.e., there were no establishment of offshore boundaries per subzone. In the original design there was no indication on the protocol nor the rules to follow when two different subzones intersected and on how to calculate the subzone coastal water boundaries when inlets lie within two $\mathrm{nm}$ of the coast. Indeed, due to the complicated geography of the islands in the Archipelago, there are many places along the Galapagos coastline where several subzones intersect. For example, in the Bolivar Channel, between Fernandina and Isabela islands, conservation, tourism and fishing subzones intersect (Figure 1A).

A portion of the coastline and coastal waters assigned to an extractive use extend to non-extractive areas, while all subzones have the two nm limit. This situation not only creates confusion in the compliance and enforcement of the reserve subzone boundaries and potential conflicts among users, but it also poses many difficulties to the calculation of extractive and non-extractive areas within the GMR coastal waters. All studies evaluating the "reserve effect" and effectiveness of the non-extractive areas to biodiversity conservation or commercial species recovery are essentially biased by their own interpretation of these conflicting areas thus rendering their comparison very difficult.

In 2014 the Galapagos National Park Directorate (DPNG) initiated the re-zoning plan process for the protected areas of Galapagos, in part, to resolve these ambiguities. However, to date, no study has addressed this issue despite the fact that the reserve has been in place for 20 years. Any study that aims at comparing the new and old zoning plans in the GMR will be faced with the interpretation of the conflicting areas, because new zoning is based on areas, not on a linear classification of the coastline.

This study aims at resolving this problem by applying spatial analysis to the old, Zoning Plan 2000, to transform a linearbased zoning to an area-based one. To do so, I explain in the methodology the steps followed to achieve this transformation and how decisions were made to tackle conflicting areas between different uses of the GMR (intersecting subzones). I then describe the outcome of the analysis and discuss the implications of this new analysis with regards to total percentage of take and no-take zones within the reserve.

\section{METHODOLOGY}

The starting point for delimiting and calculating the zoning areas is the coastline classification given by the Zoning Plan 2000 (Heylings et al., 2002). From there, following the Galapagos National Park Management Plan guidelines, the subzone coastal boundary is extended two nautical miles from the coastline. All of the resulting conflicting areas, where several uses intersect, where examined, and rules were built to resolve each of the conflicting situations until all of them where solved. The general rule that guided the decisions in conflicting areas was based on conservation priorities. All of the rules were then applied to the original coastal classification file in a GIS software (Arc GIS 10.3) to spatially represent these and to calculate the areas of each of the subzones.
For the calculations, subzones 2.1 (conservation) and 2.2 (tourism) are considered as non-extractive areas, i.e., "No-Take Zones" (NTZ), and zone 2.3 (open to fishing) as an extractive area, or "Take Zones" (TZ).

The analysis of the intersection between different uses resulted in a series of rules or assumptions depending on the type of conflict between subzone areas, namely subzone intersection and inlets within two nm from the coast (Supplementary Table 1).

\section{DATASET OUTCOMES AND DISCUSSION}

By their very nature, MPA are spatially-delimited areas of the marine environment with special management policies to achieve, among other possible goals, the conservation of biodiversity (Edgar et al., 2007). They are usually structured in order to allow different types of activities, usually termed as uses, in different areas with the help of a zoning of the area. All multi-use MPA should have, in combination with regulations, a proper zoning that clearly defines the areas dedicated to conservation of the biodiversity while other areas may allow other uses (tourism, fishing, recreation, traditional use, etc.). The different stakeholders of the MPA should ideally know where each use can and cannot take place in order to prevent use conflicts and facilitate user compliance with regulations. The Galapagos archipelago is world renown as a good example of cohabitation of human beings with the conservation of nature (despite many difficulties with invasive species associated to human activities) (Bensted-Smith, 2002). In the terrestrial realm, $97 \%$ of the territory is exclusively dedicated to the conservation of biodiversity, with very little human intervention. This achievement has been, in part, the result of an effective and clear zoning with its accompanying regulations and enforcement. Conversely, in the GMR, management policies that were defined on paper and not tested on-site resulted in unclear zoning, which created confusion and conflicts between users and resulted in poor compliance of the GMR zoning. Indeed, there is evidence that the lack of clarity with GMR' zoning has led to confusions in terms of enforcement and compliance, partially explaining the lack of "reserve effect" in NTZ, at least for some species like the red spiny lobster (Buglass et al., 2018) and the Galapagos sailfin grouper (locally known as "bacalao") (Usseglio, 2015). Of course, zoning confusion and use conflicts are not the only reasons for the lack of compliance. Law enforcement, the lack of strong fishing regulations, financial stress of public institutions, patrolling and surveillance capacity, have all been identified as challenges faced by the GMR (Castrejón and Charles, 2013; Timpe, 2016). However, thanks to this spatial analysis, management policies could be translated to the real, on-site space, allowing for a more precise, logic, objective, reproducible, and unambiguous spatial interpretation of the management policies.

Management policy decisions are usually taken at higher hierarchical levels, away from the reality of the managed areas. As in the case of the GMR, this often results in problems with the local application of the policies. The analytical methodology presented here can be used in other MPA with similar zoning 


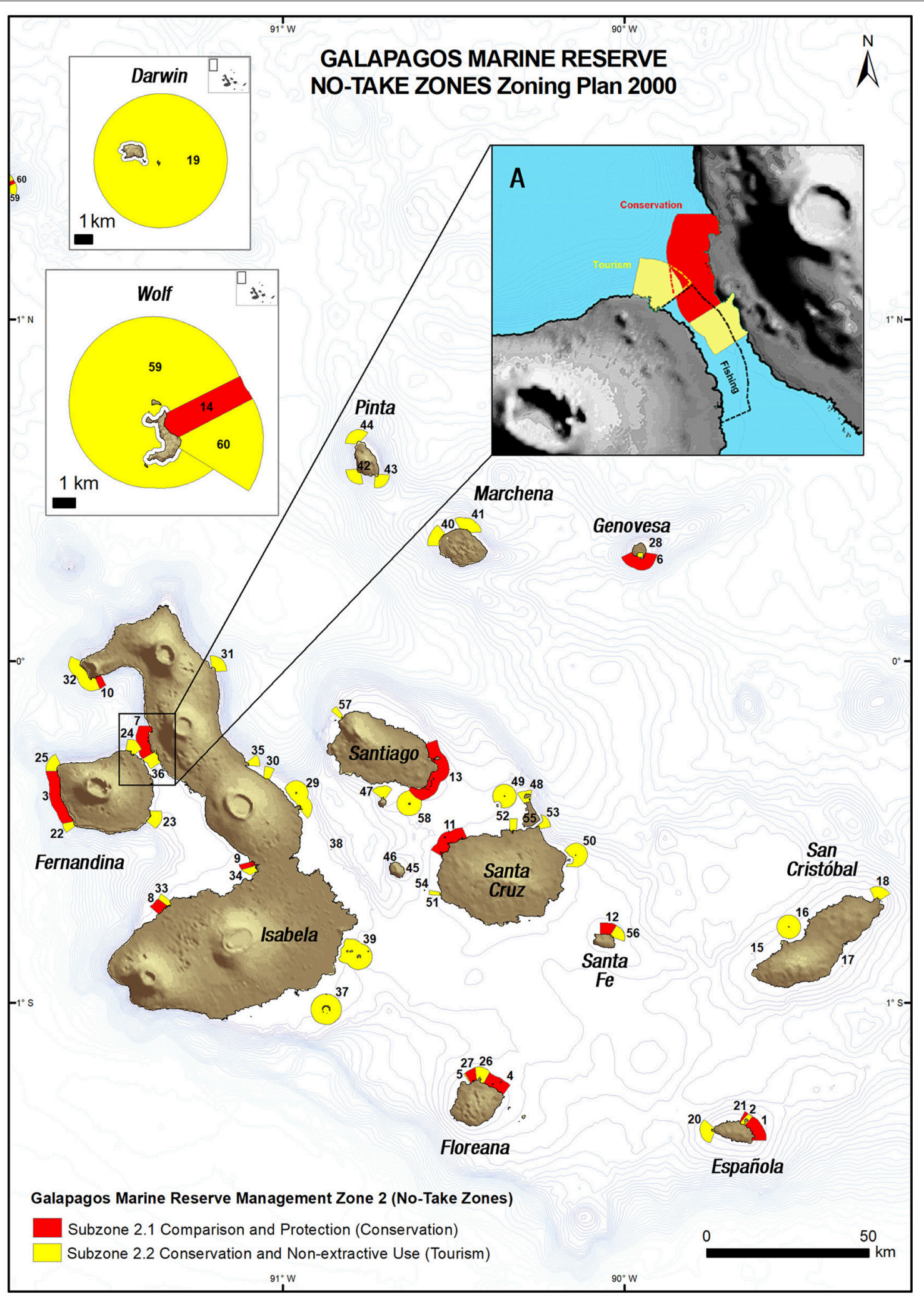

FIGURE 1 | Map of the Galapagos Marine Reserve Zoning Plan 2000 for No-Take Zones. No-Take subzones numbers refer to the subzone id and are depicted in Supplementary Table 1. Bathymetry shows isobaths at $100 \mathrm{~m}$ intervals. (A) inset shows an area where several subzones overlap creating potential conflicts between different uses. 
TABLE 1 | Comparison of No-Take Zones and Take Zones within the Galapagos Marine Reserve according to the Zoning Plan 2000.

\begin{tabular}{lcc}
\hline & Area $\mathbf{( k m}^{\mathbf{2}} \mathbf{)}$ & \% of the GMR \\
\hline No-Take Zone (NTZ) & $1,323.3$ & 0.96 \\
Conservation (subzone 2.1) & 411.6 & 0.30 \\
Tourism (subzone 2.2) & 911.7 & 0.66 \\
Take zone (TZ) & $136,676.7$ & 99.04 \\
\hline
\end{tabular}

management gaps to help ground management policies. Ideally, the management policy decisions regarding zoning of MPA should first be spatially grounded at the user level (fishers, tourists, scientists and the community) and thoroughly analyzed before it is made official so as to resolve any potential use conflict or ambiguity.

This dataset is intended to provide researchers, managers, policy makers and the broader community a useful tool in order to evaluate the NTZ effect in the GMR regarding the zoning that ruled the different uses since 2000. Detailed information of each of the NTZ and their area can be found in Supplementary Table 2, there are 14 conservation subzones (2.1) and 46 tourism subzones (2.2), totaling $60 \mathrm{NTZ}$ subzones.

Previous analyses of the Zoning Plan 2000 were based on the linear measure of the coastline for each subzone, encompassing 8,10 , and $77 \%$ of the coastline for Conservation, Tourism and Fishing subzones, respectively (Heylings et al., 2002). Thus, the resulting NTZ represented $18 \%$ of the coastline of the archipelago. However, these linear portions of the coastline should extend two nautical miles out to sea and should be analyzed as areas. With this approach in mind and considering the GMR as a whole entity where fishing can be undertaken anywhere except for the subzones 2.1 and 2.2 (excluding 2.4 Special Management Areas), according to this new dataset, the NTZ results in a total area of $1,323.3 \mathrm{~km}^{2}$. Hence, less than $1 \%$ of the GMR is protected from fishing while the rest, 99\%, remains open to fishing (Figure 1, Table 1). Furthermore, the conservation areas are extremely limited to $0.3 \%$ of the GMR.

Obviously, the area surrounding the coastline of the islands, inlets and rocks of the archipelago are extremely important for ecological processes and represent many of the relevant habitats in the archipelago, like rocky reefs, mangroves and beaches, as many marine and marine-related species inhabit those areas (Wellington et al., 1984; Edgar et al., 2004a, 2008; JiménezUzcátegui et al., 2006; Banks, 2007; Steinfurth et al., 2008; Banks et al., 2009; Llerena et al., 2012). Also, even though most of the GMR is open to artisanal fishing, most of fishing activity occurs within the proximity of the coastline for benthic and demersal species, while for pelagic species the shallow seamounts (called "bajos") are visited (Hearn, 2008; Baque-Menoscal et al., 2012; Zimmerhackel et al., 2015; Muñoz, 2016). The longest fishing trips are done between islands, to get to the fishing grounds or to farther bajos, with the longest journey being to the remote islands of Darwin and Wolf (Ruiz et al., 2016), over
$250 \mathrm{~km}$ from the closest fishing port of Puerto Ayora, Santa Cruz Island.

This dataset represents one of the multiple resolutions of the conflicting areas between overlapping subzones, however, it is based on logical assumptions. While the Zoning Plan 2000 is to be obsolete soon as a new zoning plan is being settled in place (Ministerial Agreement $\mathrm{n}^{\circ} 093$ of 1 September 2016, Environmental Ministry), this dataset remains useful for studies that aim at comparing TZ and NTZ to explore the reserve effect of NTZ (e.g., Buglass et al., 2018) and for the evaluation and comparison with the new zoning plan, which is based on areas.

\section{CONCLUSION}

This spatial analysis of the GMR Zoning Plan 2000 via a protocol, or set of rules, so as to resolve each of the conflict areas in the most objective manner, reduces the level of interpretation of this zoning plan. It is aimed at facilitating the calculation of extractive and non-extractive areas within the GMR coastal waters. Any study that aims at evaluating the "reserve effect" on target species and on the conservation of biodiversity during the 16-year period that the Zoning Plan 2000 was in place as well as comparing the Zoning Plan 2000 with the new zoning plan will benefit from this dataset.

This set of rules are translated into a map of the GMR Zoning Plan 2000 in ArcGIS (shapefile) format deposited at Pangaea, Data Publisher for Earth and Environmental Science (https://doi. pangaea.de/10.1594/PANGAEA.886891).

\section{AUTHOR CONTRIBUTIONS}

NM designed the study, collected, and processed the data through GIS software, performed the analyses, and wrote the paper.

\section{FUNDING}

This research was supported by grants to CDF by The Leona M. and Harry B. Helmsley Charitable Trust.

\section{ACKNOWLEDGMENTS}

I would like to thank the Charles Darwin Foundation and the Galapagos National Park Directorate for their institutional support to this study. This project was conducted under Galapagos National Park research permit PC-13-17. This research was supported by grants to $\mathrm{CDF}$ by The Leona $\mathrm{M}$. and Harry B. Helmsley Charitable Trust. This publication is contribution number 2203 of the Charles Darwin Foundation for the Galapagos Islands.

\section{SUPPLEMENTARY MATERIAL}

The Supplementary Material for this article can be found online at: https://www.frontiersin.org/articles/10.3389/fmars. 2018.00244/full\#supplementary-material 


\section{REFERENCES}

Banks, S. (2007). "Monitoreo ecológico submareal de las subzonas de manejo costero, 2004-2006," in Informe Galapagos 2006-2007, ed L. Cayot (Quito: Fundación Charles Darwin, Parque Nacional Galápagos e Instituto Nacional Galápagos), 132-136.

Banks, S., Vera, M., and Chiriboga, A. (2009). Establishing reference points to assess long-term change in zooxanthellate coral communities of the northern Galápagos coral reefs. Galapagos Res. 66, 43-64.

Baque-Menoscal, J., Páez-Rosas, D., and Wolff, M. (2012). Hábitos alimentarios de dos peces pelágicos Thunnus albacares y Acanthocybium solandri de la Reserva Marina de Galápagos. Rev. Biol. Mar. Oceanogr. 47, 01-11. doi: $10.4067 /$ S0718-19572012000100001

Bensted-Smith, R. (2002). A Biodiversity Vision for the Galapagos Islands. Galápagos: Fundación Charles Darwin para las islas Galápagos y Fondo Mundial para la Naturaleza.

Boerder, K., Bryndum-Buchholz, A., and Worm, B. (2017). Interactions of tuna fisheries with the Galápagos marine reserve. Mar. Ecol. Prog. Ser. 585, 1-15. doi: 10.3354/meps 12399

Bucaram, S. J., Hearn, A., Trujillo, A. M., Rentería, W., Bustamante, R. H., Morán, G., et al. (2018). Assessing fishing effects inside and outside an MPA: the impact of the Galapagos Marine Reserve on the Industrial pelagic tuna fisheries during the first decade of operation. Mar. Policy 87, 212-225. doi: 10.1016/j.marpol.2017.10.002

Buglass, S., Reyes, H., Ramirez-González, J., Eddy, T. D., Salinas-de-León, P., and Jarrin, J. M. (2018). Evaluating the effectiveness of coastal no-take zones of the Galapagos Marine Reserve for the red spiny lobster, Panulirus penicillatus. Mar. Policy 88, 204-212. doi: 10.1016/j.marpol.2017.11.028

Bustamante, R. H., Okey, T. A., and Banks, S. (2008). "Biodiversity and food-web structure of a Galapagos shallow rocky-reef ecosystem," in Food Webs and the Dynamics of Marine Reefs, eds T. R. McClanahan and G. M. Branch (New York, NY: Oxford University Press, Inc.), 238.

Castrejón, M., and Charles, A. (2013). Improving fisheries co-management through ecosystem-based spatial management: the Galapagos Marine Reserve. Mar. Policy 38, 235-245. doi: 10.1016/j.marpol.2012.05.040

Dirección del Parque Nacional Galápagos and Fundación Charles Darwin, (1999). Plan De Manejo de Conservación y Uso Sustentable de la Reserva Marina de Galápagos. Registro Oficial No. 173. 20 de abril de 1999. Galápagos: Dirección del Parque Nacional Galápagos and Fundación Charles Darwin.

Danulat, E., and Edgar, G. J. (2002). Reserva Marina de Galápagos: Línea Base de la Biodiversidad. Galápagos: Fundación Charles Darwin/Servicio Parque Nacional Galápagos.

Edgar, G. J., Banks, S., Bensted-Smith, R., Calvopi-a, M., Chiriboga, A., Garske, L. E., et al. (2008). Conservation of threatened species in the Galapagos marine reserve through identification and protection of marine key biodiversity areas. Aquat. Conserv. Mar. Freshw. Ecosyst. 18, 955-968. doi: 10.1002/aqc.901

Edgar, G. J., Banks, S., Fariña, J. M., Calvopiña, M., and Martínez, C. (2004a). Regional biogeography of shallow reef fish and macro-invertebrate communities in the Galapagos archipelago. J. Biogeogr. 31, 1107-1124. doi: 10.1111/j.1365-2699.2004.01055.x

Edgar, G. J., Bustamante, R. H., Fari-a, J.-M., Calvopiña, M., Martínez, C., and Toral-Granda, M. V. et al. (2004b). Bias in evaluating the effects of marine protected areas: the importance of baseline data for the Galapagos Marine Reserve. Environ. Conserv. 31, 212-218. doi: 10.1017/S0376892904001584
Edgar, G. J., Russ, G. R., and Babcock, R. C. (2007). "Marine protected areas," in Marine Ecology, eds S. D. Connell and B. M. Gillanders (New York, NY: Oxford University Press), 534-565.

Hearn, A. (2008). The rocky path to sustainable fisheries management and conservation in the Galapagos Marine Reserve. Ocean Coast. Manag. 51, 567-574. doi: 10.1016/j.ocecoaman.2008.06.009

Heylings, P., Bensted-Smith, R., and Altamirano, M. (2002). "Zonificación e historia de la Reserva Marina de Galápagos," in Reserva Marina de Galápagos. Línea Base de la Biodiversidad, eds E. Danulat and G. J. Edgar (Santa Cruz, CA: Fundación Charles Darwin y Servicio Parque Nacional de Galápagos), 10-22.

Jiménez-Uzcátegui, G., Mangel, J., Alfaro-Shigueto, J., and Anderson, D. J. (2006). Fishery bycatch of the Waved Albatross Phoebastria irrorata, a need for implementation of agreements. Galápagos Res. 64, 7-9.

Llerena, Y., Pe-aherrera, C., and Espinosa, E. (2012). "Nursery grounds of juvenile sharks in three coastal mangrove areas of Santa Cruz Island, Galapagos Marine Reserve," in Proceedings of the III Colombian Workshop on Condrichthyan (Santa Marta).

Muñoz, L. (2016). Ecología Trófica, Diversidad Genética y Contaminación por Mercurio del Atún aleta Amarilla (Thunnus Albacares) en la Reserva Marina de Galápagos y el Continente Ecuatoriano. Dissertation, BSc thesis, Universidad San Francisco de Quito, Quito.

Ruiz, D. J., Banks, S., and Wolff, M. (2016). Elucidating fishing effects in a largepredator dominated system: the case of Darwin and Wolf Islands (Galápagos). J. Sea Res. 107, 1-11. doi: 10.1016/j.seares.2015.11.001

Salinas de León, P., Acuña-Marrero, D., Rastoin, E., Friedlander, A. M., Donovan, M. K., and Sala, E. (2016). Largest global shark biomass found in the northern Galápagos Islands of Darwin and Wolf. PeerJ. 4:e1911. doi: 10.7717/peerj.1911

Steinfurth, A., Vargas, F. H., Wilson, R. P., Spindler, M., and MacDonald, D. W. (2008). Space use by foraging Galápagos penguins during chick rearing. Endanger. Species Res. 4, 105-112. doi: 10.3354/esr00046

Timpe, I. (2016). Informe Técnico del Diagnóstico de la Eficacia de las Herramientas de Control y Vigilancia de la RMG Como Insumo Para Promover el dise-o de un Sistema de Acatamiento. Galápagos: Parque Nacional Galápagos.

Usseglio, P. (2015). The Galapagos Grouper Fishery: Mostly Dead, Stunned, or in Need of Management Regulations? Dissertation, Ph.D. thesis, University of Hawai'i at Manoa, Honolulu, HI.

Wellington, G. M., (1984). "Marine environment and protection," in Key Environments: Galapagos, ed R. Perry (Oxford: Pergamon), 247-263.

Zimmerhackel, J. S., Schuhbauer, A. C., Usseglio, P., Heel, L. C., and Salinas-de-León, P. (2015). Catch, bycatch and discards of the Galapagos Marine Reserve small-scale handline fishery. PeerJ. 3:e995. doi: 10.7717/peer j.995

Conflict of Interest Statement: The author declares that the research was conducted in the absence of any commercial or financial relationships that could be construed as a potential conflict of interest.

Copyright (๑) 2018 Moity. This is an open-access article distributed under the terms of the Creative Commons Attribution License (CC BY). The use, distribution or reproduction in other forums is permitted, provided the original author(s) and the copyright owner(s) are credited and that the original publication in this journal is cited, in accordance with accepted academic practice. No use, distribution or reproduction is permitted which does not comply with these terms. 